\title{
ACTIVITIES OF THE U.S. SPECIAL SERVICES IN THE REPUBLIC OF CHINA DURING THE CIVIL WAR (1927-1950) ${ }^{1}$
}

\author{
Yaroslav A. Levin \\ Samara State University of Social Sciences and Education, Samara, Russian Federation
}

\begin{abstract}
Introduction. The Chinese Civil War was a time of rapprochement between the United States and the Republic of China, but there were enormous difficulties and contradictions between the two countries. Methods and materials. In this regard, it seems that the information of the two main agencies of the U.S. intelligence community is able to significantly supplement the picture of the interaction between the two countries and allows better understanding of why at some point Washington was forced to almost completely abandon its support for the Chiang Kai-shek regime. The article is based on the principles of historicism and consistency, as well as the methods of historical comparative studies. Analysis and results. The excessive level of corruption, which involved numerous American structures and officials, internal conflicts in the Republic's government that influenced the situation and the course of the confrontation and were consecrated in FBI and CIA documents, contributed to the gradual withdrawal of the United States from the policy of the unconditional support for the Chiang Kai-shek regime, but the Communist victory and the establishment of the PRC made, in the absence of other real alternatives, it necessary to continue to support the Republic. The new information makes it possible to better understand how the White House treated the leader of "democratic" China and his family, as well as to better understand the role of intelligence and counterintelligence in these processes and the place of Soviet intelligence in the final stages of the heavy civil war in China (1927-1950). The materials presented in the article and their analysis show specifics and differences in approaches of the FBI and CIA on the example of work on China. The article is based on FBI and CIA archives and covers the period from 1943 to 1949.
\end{abstract}

Key words: FBI, CIA, Chiang Kai-shek, J.Edgar Hoover, Chinese Civil War, World War Two, Cold War.

Citation. Levin Ya.A. Activities of the U.S. Special Services in the Republic of China During the Civil War (1927-1950). Vestnik Volgogradskogo gosudarstvennogo universiteta. Seriya 4. Istoriya. Regionovedenie. Mezhdunarodnye otnosheniya [Science Journal of Volgograd State University. History. Area Studies. International Relations], 2021, vol. 26, no. 1, pp. 93-106. (in Russian). DOI: https://doi.org/10.15688/jvolsu4.2021.1.9

УДК 94(73), 327.84

Дата поступления статьи: 29.04.2020

ББК 63.3(7), 66.4(4/8)

Дата принятия статьи: 12.08 .2020

\section{ДЕЯТЕЛЬНОСТЬ СПЕЦСЛУЖБ США В КИТАЙСКОЙ РЕСПУБЛИКЕ В ГОДЫ ГРАЖДАНСКОЙ ВОЙНЫ (1927-1950 гг.) ${ }^{1}$}

\author{
Ярослав Александрович Левин \\ Самарский государственный социально-педагогический университет, г. Самара, Российская Федерация
}

\footnotetext{
Аннотация. Введение. Гражданская война в Китае стала временем сближения Соединенных Штатов Америки с Китайской Республикой, однако в отношениях двух стран было огромное количество сложностей и противоречий. Методы и материальл. В связи с этим представляется, что информация двух основных ведомств разведывательного сообщества США сможет существенно дополнить картину взаимодействия двух стран и позволит лучше понять, почему в какой-то момент Вашингтон был вынужден почти полностью отказаться от поддержки режима Чан Кайши. Статья базируется на принципах историзма и системности, а также методах исторической компаративистики. Анализ и результаты. Запредельный уровень коррупции, в который были вовлечены многочисленные американские структуры и чиновники, внутренние конфликты в правительстве республики, оказывавшие влияние на обстановку и ход противостояния и освященные в документах ФБР и ЦРУ, способствовали постепенному отходу США от политики безоговорочной поддержки
} 
режима Чан Кайши, однако победа коммунистов и создание КНР сделали, в отсутствие других реальных альтернатив, необходимым продолжать поддержку Китайской Республики. Новые сведения позволяют лучше представить, как формировалось в Белом доме отношение к лидеру «демократического» Китая и его семье, а также лучше понять роль разведки и контрразведки в этих процессах и место советской разведки на заключительных этапах тяжелой гражданской войны в Китае (1927-1950 гг.). Представленные в статье материалы и их анализ показывают на примере работы по Китаю специфику и отличия в подходах ФБР и ЦРУ. Статья базируется на материалах архивов ФБР и ЦРУ и охватывает период с 1943 по 1949 год.

Ключевые слова: ФБР, ЦРУ, Чан Кайши, Дж. Эдгар Гувер, Гражданская война в Китае, Втора мировая война, холодная война.

Цитирование. Левин Я. А. Деятельность спецслужб США в Китайской Республике в годы гражданской войны (1927-1950 гг.) // Вестник Волгоградского государственного университета. Серия 4, История. Регионоведение. Международные отношения. - 2021. - Т. 26, № 1. - C. 93-106. - DOI: https://doi.org/10.15688/ jvolsu4.2021.1.9

Введение. Китай с начала XX в. представлял собой арену столкновения самых разных сил. Целый ряд европейских государств, США и Российская империя имели различные интересы и зоны влияния в этом нестабильном регионе. В годы Второй мировой войны эта страна одновременно находилась под прессом внешней агрессии Японии и страдала от Гражданской войны, очень условно прерванной общим для партии Гоминьдан и Коммунистической партии врагом. Хрупкий мир, который осознавался и в Китае, и за рубежом как временное состояние требовал от претендующих на власть в стране сил поиска мощных покровителей, которыми, исходя из общей логики международных отношений стали Советский Союз и Соединенные Штаты Америки. Начало холодной войны лишь усилило уже сложившийся в Китае «водораздел» между коммунистами и гоминьдановцами. Тем не менее отношения двух политических групп с их «покровителями» не были простыми. Цель данного исследования - проанализировать работу американских спецслужб по Китайской Республике и их роль в принятии решений по этому направлению внешней политики США.

Методы и материалы. Сложность отношений США и Китайской Республики отразилась в огромном массиве документов и исследований, в том числе и в архивах Федерального бюро расследований и Центрального разведывательного управления - сравнительно новых и малоизученных отечественными учеными ресурсах, с 2007 г. активно занимающихся рассекречиванием и оцифровкой материалов различных расследований и до- сье, собранными за долгие годы работы этих ведомств.

Архивное дело ФБР на Чан Кайши состоит из двух папок общим объемом 241 страница и охватывает период с 1943 до 1964 г. [32]. В рамках предпринятого исследования в первую очередь нас интересуют материалы папки посвященной военным годам, когда связи между лидером Исполнительного Юаня Китайской Республики и Соединенными Штатами активно интенсифицировались.

Сразу стоит остановиться на особенности досье ФБР на Чан Кайши, хотя на титульном листе и всех основных установочных документах стоит имя лидера Китайской Республики, более 90 \% архивного материала касаются его супруги Сун Мэйлин. Это не случайно, поскольку имевшая хорошее западное образование, христианка по вероисповеданию, прожившая долгое время в США первая леди Китая стала играть в этот период огромную роль в выстраивании имиджа своего супруга и его страны, а также в целом в налаживании контактов с американцами [42, p. 193].

Документы ЦРУ более разрозненны и представляют собой не какое-то централизованное дело или сборник документов, а отдельные рапорты и донесения, разделенные на тематические кейсы, которые стартуют с 1943 г. и до наших дней [16].

Анализ. Основанием для начала наблюдения за супругой китайского лидера стало письмо директора ФБР Джона Эдгара Гувера помощнику госсекретаря США Адольфу Берли. Гувер сообщил, что из источника, который он не может раскрывать, ему известно о циркулирующих слухах относительно «низ- 
кой морали» Сун Мэйлин, а также непонятных источниках доходов пары, которые «не заботят» Чан Кайши. Гувер предполагает, что Берли и Госдеп заинтересует более детальная информация об этом [24].

В данном случае мы видим пример политической хитрости, а также самостоятельности Гувера, значительно возросшей в 1940-х гг. в связи с карт-бланшем, предоставленным ему президентом Франклином Делано Рузвельтом. Дело в том, что официальное письмо в Госдепартамент направлено не случайному человеку, Адольф Берли был крайне близок к главе государства, в прошлом являлся членом его «мозгового треста» [5, с. 134, 137-138], а главное, был в хороших отношениях с Гувером и часто лоббировал его интересы в Госдепе и администрации президента. Дополнительным фактом, указывающим на неслучайность адресата, является то, что в качестве помощника госсекретаря Берли отвечал за латиноамериканское направление, а никак не за Дальний Восток [7, p. 321]. Так, Гувер намеренно направил информацию лояльному человеку, зная, что тот обеспечит формальное разрешение на расследование со стороны Кордела Халла или самого Рузвельта. Это подкрепляет и само письмо, в котором нет никаких фактов, а лишь указания на «слухи о низкой морали», что никак не могло быть важной с юридической точки зрения причиной для слежки. Более весомое обвинение в сомнительных доходах идет буквально вскользь и также ничем не подкрепляется. Тем не менее для увеличения веса высказанных обвинений Эдгар Гувер в начале письма говорит, что его конфиденциальный источник является сотрудником учреждения, название которого вымарано цензурой [24]. Представляется, что указание в письме на должность в конкретном органе, близком к супружеской чете Чан, должно было сработать и придать изложенным в письме инсинуациям необходимый вес.

Политическая самостоятельность Гувера и формальность обращения в Госдепартамент подтверждается тем, что работа по Чан Кайши и его жене уже велась. Буквально за день до письма Берли в главный офис ФБР поступает меморандум от ответственного специального агента (так в эти годы именовались руководители отделений ФБР на местах) Ман- форда на имя заместителя директора Д.М. Лэдда, которое практически дословно повторяет текст письма Гувера Адольфу Берли [27]. Это показывает, что директор просто взял первые, слабо подкрепленные доказательствами сведения и использовал их, чтобы легитимизировать дальнейшую работу. Данный вывод в целом подкрепляется стилем работы ФБР во времена директорства Гувеpa, который, получив от Франклина Рузвельта практически неограниченные с юридической точки зрения полномочия по выбору целей для расследований, активно использовал эти возможности для сбора компромата и работы по всем «подозрительным», по мнению Бюро, лицам и организациям, часто накапливая собранные без юридического основания сведения в своем сейфе [18, p. 90; 6, p. 117]. Более того, этот меморандум открывает нам информацию о «высокопоставленном источнике» ФБР, в меморандуме указывается, что агент Манфорд получил указанные сведения от сотрудника вашингтонского «Wesley Club»- престижного ресторана при «Wellesley College», который окончила мадам Чан. Таким образом, информация, на которую ссылается Гувер в следующем письме получена не от чиновника или дипломата, как явно пытается представить Эдгар Гувер в письме Берли, а от работника элитного общепита [27]. Документ агента Манфорда не выглядит как основание для начала расследования, куда больше он похож на очередной отчет об уже ведущемся расследовании. Ханна Пакула в своей подробной биографии Сун Мэйлин отмечает, что ее брат Сун Цзывэнь, министр иностранных дел Китайской Республики, заинтересовал ФБР примерно в 1940 г., когда агенты обратили внимание на странные банковские операции, которые вел дипломат. Он открывал счета в разных банках США и перечислял на них большие суммы денег, полученные от различных компаний [38, p. 217-218]. Исходя из этого, еще 15 января 1943 г. в письме Рузвельту Гувер писал, что считает, что реальная цель визита Сун Мэйлин - не поиск гуманитарной помощи для Китая и налаживание отношений, а вывод «отмытых» в США незаконных доходов назад в Китай для сохранения власти. По оценкам Гувера, Сун Мэйлин пыталась вывести из США не менее 170000000 дол- 
ларов [36]. Естественно, такая информация наверняка использовалась Рузвельтом для давления на самого Чан Кайши при переговорах.

Еще более подробным и интересным выглядит письмо от Луиса Николса, помощника замдиректора Клайда Толсона, своему начальнику. В нем подробно проанализированы связи и деятельность Сун Мэйлин в США. Николс пишет, что агентам благодаря их работе и сведениям от различных осведомителей высокого уровня удалось выяснить следующее: семья Сун является одной из богатейших и влиятельнейших в Китае, именно через нее жена Чан Кайши выводит из страны огромные денежные средства. В США деньги помогает «отмыть» еe брат Сун Цзывэнь и свояк доктор Дэвид Кунг, которые прогоняют деньги через подставные фирмы и в итоге оставляют на нескольких банковских счетах под хорошие проценты. Также в письме отмечено, что Сун Цзывэнь активно использует эти деньги еще и для коррумпирования американских чиновников, в частности конгрессменов из комитетов по международным делам, сотрудников Госдепартамента и т. д. У федеральных агентов есть все основания предполагать наличие связи семьи Сун с китайскими преступными группами [37].

Вполне понятно, что вся эта информация была своевременно предоставлена президенту, во время войны почти каждую неделю принимавшего у себя Дж. Эдгара Гувера с докладами. Поскольку в источниках и литературе не встречается никаких упоминаний об огласке этой информации Рузвельтом, вполне логично, что президент либо предпочел закрыть глаза на эти факты, поскольку и без того имел огромное влияние на Чан Кайши за счет поставок в Китай по ленд-лизу, либо, что более вероятно, использовал имеющуюся информацию для дополнительного давления на китайского коллегу при переговорах за закрытыми дверями.

Стоит заметить, что еще до этих сведений «мадам Чан» сама стремилась войти в контакт с Бюро, что видно из письма от 3 марта 1943 г. из отделения ФБР в Лос-Анджелеce (штат Калифорния). Ответственный специальный агент Худ сообщает, что Сун Мэйлин приезжала для беседы с консулом Китайской Республики Цзэ Чан Кеном, который после этого обратился в ФБР с просьбой обеспе- чить охрану Сун Мэйлин на время ее визита в США. Агент сообщает, что консулу было разъяснено, что охрана не входит в обязанности ФБР. Единственная возможность для такой работы - особый запрос из Госдепартамента [31].

Судя по всему, усилия китайской стороны по предоставлению со стороны ФБР охраны для первой леди Китая были довольно интенсивны, поскольку это потребовало специального письма от Гувера всем отделениям. Директор сообщает, что охрана мадам Чан Кайши не является задачей Бюро, однако он требует сообщать в Вашингтон о любых событиях, связанных с угрозой жизни Сун Мэйлин [25].

Снова жена Чан Кайши попала под внимание ФБР лишь в 1948 году. Она прибыла в Гонолулу и планировала перебраться в Вашингтон на самолете к 30 ноября 1948 году. Также отмечается, что за передвижениями Сун Мэйлин следит армия и флот (вероятнее всего, агент имеет в виду своих коллег из контрразведывательных ведомств армии и флота) [29].

Уже в начале мая 1949 г. в штаб-квартиру Бюро приходит сразу несколько телеграмм о супруге лидера Китайской Республики. Агенты сообщают, что Сун Мэйлин проживает в Нью-Йорке в гостиницах «Waldorf Astoria» и «Hampton Inn.», часто встречается с высокопоставленными однокурсниками из «Wellesley College», имела несколько романов за период пребывания в Нью-Йорке, оттуда планирует отправиться в Нью-Канаан (штат Коннектикут), где планирует остановиться в летнем домике, который приобрела еще в начале 1940-х гг. через своего брата [33].

Гувер требует от своих агентов продолжать слежку за контактами и передвижениями Сун Мэйлин, но напоминает, что новые китайские власти требуют экстрадиции жены Чан Кайши как государственной преступницы. Это напоминание не случайно, тем самым Гувер намекает своим агентам на необходимость особо острожного сбора информации о Сун Мэйлин, сокрытия всей официальной информации об этом от других органов власти США, поскольку это может привести к дипломатическому скандалу [23].

Еще один интересный документ в архиве - краткий меморандум на имя директора от 17 июня 1949 года. В нем ответственный спе- 
циальный агент отделения в Филадельфии сообщает, что мадам Чан Кайши не только находится в городе, но и привлекла внимание прессы, и пересылает вместе с телеграммой вырезку из газеты «Philadelphia Inquirer», датированную тем же днем, что и телеграмма [28].

В статье с характерным ироничным заголовком «Мадам Чан Кайши: женщина в изгнании живет в окрестностях Нью-Йорка. Изолированная, но деятельная “китайская Жанна д’Арк”». Автор статьи Инес Робб пишет, что прибывшая ради просьб о военной помощи для своего мужа мадам Чан Кайши с комфортом проживает в двадцатикомнатном особняке в г. Ривердейл, часто бывает в Филадельфии, где у нее, судя по всему, тоже есть недвижимость. Особняк в стиле Тюдоров был куплен в 1944-1945 гг. свояком Сун Мэйлин доктором Кунгом, ее ближайший сосед - Apтуро Тосканини, известный дирижер, с которым мадам Чан Кайши связывают «очень теплые отношения». Также журналистка описывает свой визит в особняк. Ей не удалось повидаться с хозяйкой, которая, по словам обслуги, больна. Она общалась с дворецким, молодым человеком чуть старше двадцати. В конце статьи автор делает вывод, что, несомненно, Сун Мэйлин вышла на пенсию и собирается и дальше крайне комфортно проживать в США [28].

5 июля 1949 г. в штаб-квартиру Бюро поступает крайне интересный документ - это донесение из офиса в Гонолулу. Агенты этого отделения восстановили путь Сун Мэйлин из становящегося с каждым днем более опасным Китая. Они сообщают о том, что она прибыла в столицу на частном самолете, который через 48 часов отправился в Гонолулу, что члены семьи Чан Кайши везли с собой ценности и несколько ящиков имущества. За почти два дня остановки в Вашингтоне китайцы активно встречались с различными чиновниками, в основном из Госдепартамента и Конгресса (все имена вымараны). Кроме того, Сун Мэйлин за время остановки посетила несколько магазинов и купила драгоценностей на 4000 долларов, по примерной оценке федеральных агентов. После этого самолет отправился в Гонолулу, где были приготовлены дома и номера в дорогих гостиницах для членов семьи лидера Китайской Республики [30].
Пожалуй, самый интересный документ в архиве за рассматриваемый период - это письмо Эдгара Гувера военному советнику президента Трумэна Гарри Вону. Большая часть переписки Гувера с Белым домом во времена Гарри Трумэна шла именно через его советника Гарри Вона, это связано с тем, что практически с первых недель работы в Белом доме у Трумэна сложились неприязненные отношения с директором, поэтому, понимая важность информации, предоставляемой ФБР, президент предпочел перепоручить все контакты своему доверенному советнику [19, p. 52].

Глава Бюро сообщает, что по сведениям, полученным от высокопоставленного информатора, в период от двух до трех недель после 30 июня 1949 г. из провинции Кантон в Вашингтон вылетел частный самолет с женой Чан Кайши и остальными членами его семьи. Самолет был зарегистрирован на «Philippine Airlines Company». Далее Гувер сообщает, что его источник не смог быстро передать информацию, поэтому она поступила с некоторой задержкой. Далее он пишет, что готов передать больше сведений как можно скорее. Стоит обратить внимание, что большая часть этого письма идентична первым параграфам сообщения от отделения ФБР в Гонолулу от 5 июля [26].

С учетом предыдущей, крайне компрометирующей Чан Кайши и его супругу информации, с которой президент Трумэн не мог быть не знаком, представляется, что Гувер намеренно дает лишь самые безобидные сведения чтобы «выбить» личную встречу с президентом и показать свою полезность, сообщив подробные сведения о деятельности Сун Мэйлин и ее семьи, которые хранились в его сейфе.

Директор ФБР использовал имеющиеся у него сведения, дабы упрочить и по возможности улучшить свои отношения с главой государства. Стоит отметить, что в так называемой «потере Китая», как окрестили проигрыш Чан Кайши и создание КНР в американской прессе, действительно немалую роль сыграли сведения спецслужб. И Рузвельт, и Трумэн были достаточно осведомлены о том, что большая часть оказываемой США помощи Китайской Республике банально разворовывается. Однако оба президента до определенного момента мирились с этим. Франкли- 


\section{СПЕЦСЛУЖБЫ И НАЦИОНАЛЬНАЯ БЕЗОПАСНОСТЬ}

на Рузвельта сковывали интересы ведения Второй мировой войны и важность китайского театра военных действий как для боевых действий против японцев, так и в перспективе развития послевоенного мира. Гарри Трумэн оказался скован условиями начинающейся холодной войны, а потому был вынужден поддерживать Китайскую Республику. Однако чем дольше и неудачнее шли боевые действия, тем явственнее становилось разочарование Вашингтона в лидерах противников коммунистов. Это разочарование вылилось в сокращении помощи США правительству Чан Кайши, что во многом и привело к победе коммунистов и провозглашению Китайской Народной Республики.

Впрочем, «потеря Китая» вынудила Белый дом закрыть глаза на откровенно преступное поведение Чан Кайши и его семьи, поэтому снабжение правительства Китайской Республики в изгнании продолжалось и после 1949 г. [39, р. 277].

В связи с этим интересно взглянуть на данные американской разведки относительно Исполнительного Юаня Китайской Республики и его председателя. Прежде чем приступить к анализу взгляда ЦРУ на деятельность руководства Китайской Республики, имеет смысл вкратце осветить саму историю развития Центрального разведывательного управления и его резидентур в Китае.

13 июня 1942 г. было создано Управление стратегических служб (далее - УСС) первая объединенная разведывательная служба в истории США. Ее возглавил Уильям Донован, за свой резкий нрав и бескомпромиссность получивший прозвище «Дикий Билл». Нужды военного времени и идея Рузвельта о «четырех полицейских» требовали от Донована создания в Китае развитой резидентуры, что и было сделано и довольно быстро. Уже в 1944-1945 гг. УСС получает из Китая исчерпывающую информацию обо всех основных игроках. В блестящем исследовании профессора Военно-морской академии США Маочун Ю досконально изучено, как Доновану удалось выстроить развитую сеть сбора информации, притом не только в стане армии гоминьдановцев, но и на высших уровнях руководства КПК. Успех Донована связан с использованием корейской диаспоры в Китае, находящейся на положении людей второго сорта и занимающих преимущественно должности в обслуживающем персонале. Обученные по приказу Донована корейцы стали идеальными и незаметными шпионами для сбора информации и вербовки китайских чиновников разного ранга в обеих противоборствующих группировках, кроме того, активно использовались двойные агенты и перебежчики, а также данные других разведок, действующих в регионе [44, p. 20-130].

Действительно, даже беглого взгляда на документы УСС этого времени достаточно, чтобы сделать вывод об информированности американской разведки о состоянии дел в Китае $[11 ; 14 ; 15]$.

Серьезные перемены в работе американской разведки произошли после 1945 г., когда по приказу президента Гарри Трумэна было распущено УСС. Роспуск был связан с рядом объективных и субъективных факторов. К объективным можно отнести сравнительную компактность УСС, явно не способного в том виде, в каком оно существовало, стать службой разведки охватывающей весь мир. УСС было в большей степени ориентировано на тактическую разведку и различные диверсии, что было ценно в условиях военного времени, но куда меньше подходило нуждам нового мира и разгорающейся холодной войны. Говоря о субъективных факторах, нельзя не отметить неприязненные отношения, сложившиеся между новым президентом и главой УСС Донованом. «Дикий Билл» считал Трумэна некомпетентным «зеленым» дилетантом, не понимающим тонкости работы разведки и не способным адекватно использовать имеющийся ресурс и получаемую через него информацию. Тяжелый характер «Дикого Билла» привел к тому, что он не стеснялся говорить о своем мнении насчет компетентности нового президента многим важным чиновникам из Конгресса, Госдепартамента, Министерства обороны и других органов власти [43, p. 315-341]. Обо всех этих фактах оперативно рапортовал Трумэну Эдгар Гувер, по ряду причин активно следящий за Уильямом Донованом как минимум с 1928 г. [2, с. 226-233]. Впрочем, не стеснялся шеф УСС в выражениях и во время встреч с самим главой Овального кабинета, что сделало лишь вопросом 
времени его отставку. Однако под влиянием своих советников президент пошел дальше и полностью распустил УСС. Первоначально агентов-аналитиков забрал себе Госдепартамент, а действующие разведчики оказались в подчинении министерства обороны, впрочем, очень быстро такая система показала свою полную негодность и уже в 1946 г. была создана Центральная разведывательная группа (далее - ЦРГ), в которой сохранялось условное разделение «аналитиков» и «оперативников», но теперь они должны были плотно взаимодействовать друг с другом. Впрочем, создание ЦРГ изначально было вынужденной мерой, направленной на выигрыш времени для подготовки проекта новой спецслужбы, качественно превосходящей и УСС, и, естественно, ЦРГ. Итогом этой работы стало создание в 1947 г. Центрального разведывательного управления (далее - ЦРУ). Впрочем, серьезную силу ЦРУ начало представлять из себя еще очень нескоро и вплоть до 1953-1955 гг. с приходом Аллена Даллеса, начавшего наращивать активность ведомства, новое управление было структурой слабой и во многом зависимой [40, p. 117].

Естественно, все эти перемены отразились и на работе разведки по Китаю. В период с 1945 по 1947 гг. многие документы были просто утрачены, связь со многими агентами и завербованными ими лицами потеряна. Фактически в 1947 г. ЦРУ было вынуждено начинать активную работу по этому направлению практически с начала, что сказалось на качестве информации, а главное, на тех действиях, которые разведка предпринимала исходя из имеющейся информации [20, p. 1-29].

Одним из наиболее ранних документов УСС, сохраненных ЦРУ и доступных для исследователей, является доклад Уильяма Донована президенту Рузвельту о выходе книги Чан Кайши «Судьба Китая». Глава Управления стратегических служб сообщает, что выход англоязычного текста планируется через несколько месяцев. Далее идет подробный анализ книги. Агенты УСС изучили каждую главу и подробно описали ее содержание. Интерес в данном случае представляет итоговое заключение, направленное Доновану и президенту [9].

Книга Чан Кайши названа пропагандистским памфлетом, в котором генералиссимус прославляет себя, отмечаются и довольно подробно разбираются многочисленные отсылки к философии Сунь Ятсена, однако интерес к ним не вошел в итоговый документ для шефа УСС и президента. По мнению агентов, отдельные главы книги проникнуты духом китайского национализма и неприязни, граничащей с ненавистью к белому человеку. В «Судьбе Китая» критикуется колониализм во всех его проявлениях, высказываются многочисленные претензии к западным странам. По мнению авторов отчета, эта книга в большей степени предназначалась для внутреннего обращения, и их даже несколько удивляет, что окружение генералиссимуса пожелало издать ее в США. Более того, как написано в отчете, с Чан Кайши было заключено эксклюзивное соглашение, по которому он не только получил солидное вознаграждение в виде 550000 долларов, но и должен был получить процент с продаж, также книга должна была быть направлена ограниченными тиражами в библиотеки военных и военно-морских учебных заведений США, что особо тревожит агентов. Сотрудники УСС считают, что возможно имела место настоящая диверсия, поскольку издание «Судьбы Китая» в полном виде скорее испортит отношения Вашингтона и Чунцина [9].

Кроме президента с отчетом агентов УСС был ознакомлен Локлин Карри. В правительстве Франклина Рузвельта он занимал должность экономического советника, в годы Второй мировой войны именно Карри взял на себя контакты с правительством Китайской Республики для определения масштабов помощи для армии Чан Кайши по ленд-лизу, став фактически «главным по Китаю» в окружении президента. В 1948 г. был обвинен в сотрудничестве с советской разведкой. Хотя в западной историографии существует мнение о невиновности Карри [8, р. 73-99], авторитетный отечественный ученый В.В. Поздняков твердо заявляет о факте его работы на разведку СССР [4, с. 467].

Изучение этого доклада разведки представляет отдельный интерес, особенно если сравнить информацию УСС и данные ФБР. Практически одновременно с УСС федеральные агенты подготовили свой отчет. Вариант ФБР наглядно показывает отличия в подходе 
двух служб к предмету изучения. Федеральные агенты менее подробны, обращают мало внимания на философско-политические взгляды Чан Кайши, но так же, как и сотрудники УСС, обращают внимание на откровенно националистический характер книги. По их мнению, издание этой книги может спровоцировать агрессию со стороны китайской диаспоры в США, число представителей которой неуклонно увеличивается. Также работники Федерального Бюро расследований тщательнее изучили вопросы издания книги, они отмечают, что представителями Чан Кайши, занимавшимися подготовкой книги к изданию и контактами с издательством (название издательства вымарано в документах обеих служб), были Сун Мэйлин и Локлин Карри, притом если «мадам Чан Кайши» выступила лишь формальным представителем, от имени мужа давшим «добро» на издание, то именно Локлин Карри был ответственен за подготовку рукописи и контакты с редакторами и переводчиками. Так, Карри прекрасно представлял содержание книги и тот негативный эффект, который повлекло бы за собой ее издание «без купюр». По мнению Гувера, «это вызывает вопросы». Также Гувер считает, что часть тех денег, которые получила Сун Мэйлин, были переданы Карри за «посреднические операции» [35; 34].

С учетом практически не вызывающих сомнений связей Локлина Карри с разведкой СССР представляется, что он намеренно способствовал выходу в свет подобной книги, которая вызвала бы негативную реакцию общества и СМИ, что отрицательно бы сказалось на отношениях США и Китайской Республики.

В итоге книга Чан Кайши вышла в 1944 г. со значительными купюрами и небольшим тиражом, а в 1947 г. переиздана, стоит отметить, что наиболее экстравагантные пассажи наполненные критикой и даже отвращением к «белому человеку», из издания 1944 г. были убраны. Впрочем, книга все равно была проникнута критикой колониализма и западного образа жизни [21, p. 3-68]. С ее выходом связан интересный случай. Дело в том, что переизданию книги способствовал Филип Джаффе (встречаются написания Яффе и Джейф), известный бизнесмен, публицист, главный редактор журнала «Амеразия», уже в 1945 г. оказавшегося под пристальным вниманием ФБР. Это издание оказалось в центре скандала, когда агенты УСС вскрыли использование секретной документации для написания ряда статей, критических по отношению к политике США и Великобритании в Китае и в целом в Азии. Филип Джаффе в итоге отделался лишь небольшим штрафом по итогу досудебного соглашения. «Дело “Амеразии”» впоследствии стало одним из первых эпизодов нараставшего движения маккартистов [3, с. 87-96].

Кроме Джаффе изданию книги способствовал Джон Сервис, еще один фигурант «дела “Амеразии”», сотрудник Госдепартамента, впоследствии уволенный в ходе разбирательства, санкционированного Джозефом Маккарти и его сторонниками. Хотя в западной историографии существуют некоторые сомнения относительно связей «Амеразии» с советской разведкой, авторитетный отечественный исследователь А. Колпакиди убедительно и уверенно заявляет о том, что редакция журнала «Амеразия» активно использовалась советской разведкой для получения секретных документов разных органов власти США [1, с. 64]. Также вновь представителем автора выступила его супруга Сун Мэйлин. Выход книги сопровождался довольно резкой критикой в прессе, даже ее обложка, на которой под портретом Чан Кайши находилась надпись «Антизападный феодал», вызвала критику [41, p. 331-335].

Таким образом, можно сделать вывод, что идея с дискредитацией Китайской Республики и ее лидера в глазах общественного мнения была удачно реализована, хоть и позже, чем планировалось изначально. Это значительно усложнило для администрации Трумэна поддержку армии генералиссимуса Чан Кайши, что не в последнюю очередь также способствовало «потере Китая» для Америки.

Если ФБР все же больше было ориентировано на дела Чан Кайши и его семьи в США, то недавно образованное ЦРУ стремилось представить главе государства и правительству более полную картину действий лидера Китайской Республики дома. Маочун Ю в своей работе и вовсе отмечает, что, несмотря на амбиции Эдгара Гувера, стремившегося получить для своего ведомства разведывательные полномочия, Китай для федеральных агентов оставался «темным лесом» [44, p. 180]. 
Это подтверждает небольшой доклад от 21 августа 1947 г., посвященный отношениям между Сун Цзывэнем и Чан Кайши. Отмечается, что идея с назначением Суна премьером вызвала негативную реакцию у генералиссимуса, однако агенты считают, что его назначение - дело почти решенное, поскольку министр иностранных дел пользуется поддержкой не только сторонников генералиссимуса, но и оппозиционных группировок внутри Гоминьдана, что делает его идеальным лидером. Это понимает и сам глава «демократического» Китая, поэтому он и выступает против назначения, придумывая различные предлоги, по которым родственник его жены не может занять эту должность. Впрочем, агенты считают страхи Чан Кайши преувеличенными, по их мнению, Сун Цзывэнь не рискнет смещать генералиссимуса, однако имеет все шансы занять его место после смерти или отставки последнего. Более того, агенты ЦРУ считают такое назначение целесообразным, а Суна - удобным кандидатом [17].

Интересен в этом плане также доклад от 25 августа 1948 г. под заголовком «Политическая информация: советники и персонал президента Чан Кайши». Небольшая двухстраничная справка содержит список всех наиболее близких к генералиссимусу людей, их должности. Кроме персоналий, коротко проанализировано, кому глава Китайской Республики доверяет больше, кому чуть меньше. В целом документ довольно небольшой (всего две страницы), значительная часть вымарана, однако даже то, что доступно исследователям, показывает, насколько важен был Китай и насколько интересовало американцев положение дел в стане сторонников Гоминьдана [13]. С учетом информации о разворовывании гуманитарной помощи и денежных вливаний, а также военных неудач Чан Кайши неудивительно, что Трумэн желал иметь полное представление обо всей верхушке Исполнительного Юаня и ее работе. Тем не менее краткость этого доклада свидетельствует о том, что ЦРУ еще явно не оправилось от бюрократических потрясений 1945-1947 гг., а потому не могло дать президенту более полную информацию. Однако ФБР, жаждавшее «забрать» себе и разведку, не могло дать и этого.
Очень интересным выглядит рапорт от 18 января 1949 г., посвященный «Народному движению мира»-оппозиционной группировке внутри Китайской Республики. Ее лидеры Чанг Ченхуа и Лю Путунг выступали за мир любой ценой [10]. Достаточно быстро движение получило определенную поддержку. Сторонники этой группы считали невозможным для Китая дальнейшее ведение гражданской войны, а потому предлагали создать «правительство национального согласия», в котором значительное представительство получили бы коммунисты. В основном «Народное движение мира» состоит из наиболее молодых и прогрессивных представителей партии Гоминьдан. Кроме заявленных в докладе лидеров, отмечены два наиболее высокопоставленных члена - это Ли Цзуньжэнь и Шао Лицзу, которые занимаются выстраиванием связей между их организацией и меньшими партиями Китая, а также пытаются найти контакты в Революционном комитете Гоминьдана. Особо активна деятельность оппозиционеров, когда генералиссимус Чан Кайши покидает Нанкин, вероятнее всего, имеется в виду подготовка отхода сторонников Гоминьдана на Тайвань. Почти все представители этого движения считают необходимым отправку Чан Кайши в отставку, поскольку он является «символом войны», которого не примут коммунисты, не желает идти на компромиссы, боится утратить власть. Новый глава «правительства национального согласия» не должен быть связан с продолжающейся гражданской войной [10].

Далее в документе сообщается, что Тайная полиция начала аресты сторонников отставки Чан Кайши в Нанкине, пока не были арестованы никакие официальные лица. Отмечается, что кроме арестов имели место и убийства наиболее заметных представителей «Народного движения мира». По мнению агентов ЦРУ, Чан Кайши пока не решается ударить по наиболее высокопоставленным оппозиционерам. В ответ на начавшиеся преследования Ли Цзуньжэнь заявил, что все, кто опасается за свою жизнь и жизнь близких, могут найти убежище на территориях, управляемых «Гуансийской кликой». В период «эры милитаристов» (1916-1928 гг.) Китай управлялся военными правителями (дуцзюнями), 


\section{СПЕЦСЛУЖБЫ И НАЦИОНАЛЬНАЯ БЕЗОПАСНОСТЬ}

после объединения страны под флагами Гоминьдана и КПК значительная часть дуцзюней, их семей и союзников стали занимать высокие посты в высших кругах двух соперничающих партий. Тем не менее различные «клики» сохраняли значительную самостоятельность, часто преследовали свои узкие интересы, что усложняло ведение войны для правительства Гоминьдана. Гуансийская клика, первоначально не самая большая и авторитетная, с образованием Китайской Республики стала одной из важнейших, подчинила себе провинции Хунань и Гуандун и стала играть значительную роль в политике республики [22, p. 136-150].

По мнению агента, подготовившего данный документ, это будет означать окончательный разрыв Чан Кайши с авторитетными семьями провинции Гуанси, что в условиях тяжких военных поражений от коммунистов губительно [10].

Хотя документ и небольшой (всего одна страница), мы видим, что ЦРУ в меру своих возможностей пыталось изучить все тонкости китайской политики и довольно успешно развивало свои знания о регионе, понимая проблемы различных «клик» и «кланов» и прекрасно осознавая сложную ситуацию, в которой оказался Чан Кайши. Однако заметно, что его затруднения не вызывают у американских разведчиков желания помочь или какогото сочувствия, с учетом даты документа понятно, что в Управлении и Белом доме уже догадывались, что Китай «потерян» и теперь скорее обдумывали новую стратегию. Затруднения лидера Китайской Республики выглядят в документах американской разведки, скорее, логичным продолжением его политики и общего краха армии Гоминьдана. Хоть и коротко, но в рапорте отмечено, что подавляющее большинство населения жаждет мира любой ценой, пусть и путем соглашения с коммунистами. Это выглядит явным показателем провала политики Чан Кайши, его военных талантов и общей усталости всех слоев населения. Более того, агенты во многом оказались правы, поскольку буквально через несколько дней Чан Кайши был вынужден уйти в формальную отставку на фоне очевидного поражения войск Китайской Республики, вместе с тем он не желал мириться с этим и не желал при- нимать в качестве действующего президента Ли Цзунжэня, навязанного ему в качестве вице-президента Национальной ассамблеей Китайской Республики.

Еще более показательным глубокий политический кризис в Китайской Республике выглядит в донесении от 22 апреля 1949 г. [12]. На фоне очевидных военных поражений в период, когда правительство Китайской Республики больше было занято грядущим «Великим отступлением» на Тайвань, состоялось заседание Исполнительного комитета Гоминьдана. На этом заседании Чан Кайши заявил, что он и верные ему люди не принимают Ли Цзунжэня в качестве президента и требуют его скорейшей сдачи. Исполнительный комитет оказался в замешательстве, поскольку именно Чан Кайши выстроил контакты с западными странами, в первую очередь США, так необходимые в данный момент Китайской Республике, поэтому было принято решение просить генералиссимуса вернуться. Решимость комитета укрепило заявление, что провинция Квантун полностью поддержит Чан Кайши. Это заявление было получено после того, как источники ЦРУ - Ву Тэчень и Хуанг Шаохаюн - встретились с неким Чиковым. После этого Исполнительный комитет предпочел поддержать возвращение Чан Кайши к власти, хотя обсуждение было длительным и сопровождалось спорами [12].

В данном документе мы видим, что, судя по всему, ЦРУ не стеснялось использовать двойных агентов имеющих контакты как с американской, так и с советской стороной. Встреча с Чиковым и угроза поддержки находящегося под советским влиянием Квантуна оказалась, судя по документу, чуть ли не решающим фактором, заставившим Исполнительный комитет Гоминьдана перейти на сторону Чан Кайши.

Результаты. В документах американских спецслужб мы явно видим все недостатки, приведшие к поражению и последующему отступлению Китайской Республики на Тайвань. Запредельная коррупция семьи Чан Кайши, его военные неудачи, раздоры внутри правительства сделали генералиссимуса слабой и неудобной фигурой для США, однако в условиях изгнания Гоминьдана и ос- 
нования 1 октября 1949 г. Китайской Народной Республики у Вашингтона просто не было альтернативы для противодействия китайским коммунистам. Очевидно, особенно из последнего документа, что коррумпированное и раздираемое внутренними противоречиями правительство Китайской Республики было удобно и СССР, поэтому в период отстранения от власти Москва через своего представителя и предложила помощь Чан Кайши. Кроме того, рассмотренные документы убедительно показывают отличия в стиле работы и подходах двух крупнейших спецслужб Соединенных Штатов. Так, ФБР сосредоточивалось, в силу своих функций и специфики, на вопросах «внутриамериканских», изучало коррупционную схему семьи Чан Кайши и деятельность его сторонников в США, в то время как ЦРУ больше сфокусировалось на политических перипетиях в самой Китайской Республике. Вполне понятно, что информация спецслужб по Китайской Республике и ее лидеру стала одним из факторов постепенного ослабления поддержки режима Чан Кайши Вашингтоном, что способствовало победе китайских коммунистов и созданию КНР.

\section{ПРИМЕЧАНИЕ}

${ }^{1}$ Исследование выполнено при финансовой поддержке РФФИ в рамках научного проекта № 20-39-70003 «“Сражающийся Китай” 19311949 гг. в оценках периодической печати США».

The reported study was carried out in the framework of RFBR grant no. 20-39-70003 “"Fighting China' 1931-1949 in the US press estimates".

\section{СПИСОК ЛИТЕРАТУРЫ}

1. Колпакиди, А. И. ГРУ в Великой Отечественной войне / А. И. Колпакиди. - М. : Яуза, 2010. -608 c.

2. Левин, Я. А. Гувер против Донована. Истоки соперничества ФБР и ЦРУ / Я. А. Левин // Новая и Новейшая история. - 2017. - № 5 (17). - С. 226-233.

3. Левин, Я. А. «Дело «Амеразии»-на пороге маккартизма / Я. А. Левин // ОбозревательObserver. - 2016. - № 10 (321). - C. 87-96.

4. Позняков, В. В. Советская разведка в Америке. 1919-1941 / В. В. Позняков. - М. : Международные отношения, 2015. $-584 \mathrm{c}$.
5. Яковлев, Н. Н. Неизвестный Рузвельт. Нужен новый курс! / Н. Н. Яковлев. - М. : Эксмо, 2012. $-496 \mathrm{c}$.

6. Batvinis, R. J. The Origins of FBI Counterintelligence / R. J. Batvinis. - Lawrence : University Press of Kansas, 2007. - 344 p.

7. Berle, B. B. Navigating the Rapids, $1918-$ 1971: From the Papers of Adolf Berle / B. B. Berle, T. B. Jacobs. - N. Y. : Harcourt Brace Jovanovich, 1973. $-859 \mathrm{p}$.

8. Boughton, J. Politics and the Attack on FDR's Economists: From Grand Alliance to Cold War / J. Boughton, R. Sandilands // Intelligence and National Security. - 2003. - № 17. - P. 73-99.

9. OSS - Book Entitled "China's Destiny" by Chiang Kai-shek, 1943. 23 March 1944 // CIAArchive (далее-CIA).-CIA-RDP13X00001R000100190002-2.

10. 1. People's Peace Movement in Legislative Yuan 2. Arrests of Favoring of Those Favoring Retirement ofChiang Kai-shek. 18 January 1949 // CIA. CIA-RDP82-00457R002300040010-5.

11. Political Dynamics of China's Northwest. 5 June 1944 // CIA. - CIA.0000710371.

12. Political Information: Possibility of Chiang Kaishek Resuming Office in National Government. 22 April 1949//CIA. -CIA-RDP82-00457R002700090003-4.

13. Political Information: President Chiang Kaishek's Advisers and Personal Staff. 25 August 1948 // CIA. -CIA-RDP82-00457R001800480010-3.

14. Recent Events and Trends in China. 5 September 1944 // CIA. - CIA. 0000710373.

15. Tab. 'A.A.' (Map) Japanese and Chinese Held Areas in China (Kuang-Chou (Canton) (1944 Ed.) and Tab. 'A.B.' (Map) Situation - China - 1 February 1945 (5 Feb. 1945 Ed.). 5 February 1945 //CIA. -CIA-RDP7200121A000100170001-5.

16. China. Table of Contents // CIA.

17. T.V. Soong and Chiang Kai-shek. 21 August 1947 // CIA. - CIA-RDP82-00457R000800560009-7.

18. Charles, D. J. Edgar Hoover and the AntiInterventionists: FBI Political Surveillance and the Rise of the Domestic Security State, 1939-1945 / D. Charles. Columbus: Ohio State University Press, 2007. - 197 p.

19. Gardner, M. Harry Truman and Civil Rights / M. Gardner. - N. Y. : Southern Illinois University Press, 2002. $-320 \mathrm{p}$.

20. Jeans, R. B. The CIA and Third Force Movements in China during the Early Cold War: The Great American Dream / R. B. Jeans. - Lanham : Lexington Books, 2018. -342 p.

21. Kai-shek, C. China's Destiny \& Chinese Economic Theory/C. Kai-shek. - N. Y. : Roy Publishers, 1947. $-347 \mathrm{p}$.

22. Lary D. Region and Nation: the Kwangsi Clique in Chinese Politics, 1925-1937 / D. Lary. - L. : Cambridge University Press, 1974. - 292 p. 
23. Hoover to All. 6 May 1949 // National Archives and Records Administration. Record Group 65. Federal Bureau of Investigation (далее-NARA. RG 65. FBI).File: 62-7/649 (Chiang Kai-shek).

24. Hoover to Berle. 5 March 1943 // NARA. RG 65. FBI. - File: 62-7/649 (Chiang Kai-shek).

25. Hoover to San Francisco FBI and All. 9 March 1943 // NARA. RG 65. FBI. - File: 62-7/649 (Chiang Kai-shek).

26. Hoover to Vaughan. 8 July 1949 // NARA. RG 65. FBI. - File: 62-7/649 (Chiang Kai-shek).

27. Memo for D.M. Ladd. 4 March 1943 // NARA. RG 65. FBI. - File: 62-7/649 (Chiang Kai-shek).

28. Memo from Philadelphia Office to Director. 17 June 1949 // NARA. RG 65. FBI. - File: 62-7/649 (Chiang Kai-shek).

29. Radiogram from Honolulu office to $\mathrm{HQ}$. 29 November 1948 // NARA. RG 65. FBI. -File: 62-7/649 (Chiang Kai-shek).

30. SAC, Honolulu to Director. 5 July 1949 // NARA. RG 65. FBI. - File: 62-7/649 (Chiang Kai-shek).

31. SAC Hood to Director. 3 March 1943 // NARA. RG65. FBI. -File: 62-7/649 (Chiang Kai-shek).

32. Table of Contents // NARA. RG 65. FBI. File: 62-7/649 (Chiang Kai-shek).

33. Teletype from New York Office to HQ. 5 May 1949 // NARA. RG 65. FBI. - File: 62-7/649 (Chiang Kai-shek).

34. Hoover to Berle. 23 March 1944 // NARA. RG 65. FBI. - File: 67-571 (J. Edgar Hoover's Official and Personal Letters - China).

35. Hoover to Watson. 25 March 1944 // NARA. RG 65. FBI. - File: 67-571 (J. Edgar Hoover's Official and Personal Letters - China).

36. Memo from Director Hoover to Lawrence M.C. Smith, Chief of Special War Policies Unit. 15 January 1943 // NARA. RG 65. FBI. - File: 67-571 (J. Edgar Hoover's Official and Personal Letters China).

37. Memo re: Soong Family. L.B. Nichols to Mr. Tolson. 8 February 1943 // NARA. RG 65. FBI. File: 67-571 (J. Edgar Hoover's Official and Personal Letters - China).

38. Pakula, H. The Last Empress: Madame Chiang Kai-shek and the Birth of Modern China / H. Pakula. N. Y. : Simon \& Schuster, 2009. - 816 p.

39. Tanner, H. M. Where Chiang Kai-shek Lost China: The Liao-Shen Campaign, 1948 / H. M. Tanner. N. Y. : Indiana University Press, 2015. - 384 p.

40. The Central Intelligence Agency: History and Documents / ed. by W. M. Leary. - N. Y. : University Alabama Press, 1984. - 200 p.

41. Toller, W. S. China's Destiny by Chiang KaiShek; China's Destiny and China's Economic Theory by Chiang Kai-shek, Philip Jaffe / W. S. Toller // Pacific Affairs. - 1947. - Vol. 20, № 3. - P. 331-335.
42. Tyson, Li L. Madame Chiang Kai-shek: China's Eternal First Lady / L. Li Tyson. - N. Y. : Grove Press, 2006. $-576 \mathrm{p}$.

43. Waller, D. Wild Bill Donovan: The Spymaster Who Created the OSS and Modern American Espionage / D. Waller. - N. Y. : Free Press, 2012. -480 p.

44. Yu, M. M. OSS in China: Prelude to Cold War/ M. M. Yu.-Annapolis: Naval Institute Press, 2011. -368 p.

\section{REFERENCES}

1. Kolpakidi A I. GRUv Velikoj Otechestvennoj vojne [GRU in Great Patriotic War]. Moscow, Yauza Publ., 2010. 608 p.

2. Levin Ia.A. Guver protiv Donovana. Istoki sopernichestva FBR i CRU [Hoover vs. Donovan: The Origins of Rivalry Between the FBI and the CIA]. Novaja i Novejshaja istorija [Modern and Current History Journal], 2017, no. 5 (17), pp. 226-233.

3. Levin Ia.A. «Delo "Amerazii”» - na poroge makkartizma [Amerasia Case - At the Threshold of McCarthyism]. Obozrevatel-Observer, 2016, no. 10 (321), pp. 87-96.

4. Poznjakov V.V. Sovetskaja razvedka $v$ Amerike. 1919-1941 [Soviet Intelligence in America. 1919-1941]. Moscow, Mezhdunarodnye otnosheniya Publ., 2015. 584 p.

5. Jakovlev N.N. Neizvestnyj Ruzvel't. Nuzhen novyj kurs! [Unknown Roosevelt. Need a New Deal]. Moscow, Eksmo Publ., 2012. 496 p.

6. Batvinis R.J. The Origins of FBI Counterintelligence. Lawrence, University Press of Kansas, 2007. 344 p.

7. Berle B.B., Jacobs T.B. Navigating the Rapids, 1918-1971: From the Papers of Adolf Berle. New York, Harcourt Brace Jovanovich, 1973. 859 p.

8. Boughton J., Sandilands R. Politics and the Attack on FDR's Economists: From Grand Alliance to Cold War. Intelligence and National Security, 2003, no. 17, pp. 73-99.

9. OSS - Book Entitled "China's Destiny" by Chiang Kai-shek, 1943. 23 March 1944. CIA Archive (CIA). CIA-RDP13X00001R000100190002-2.

10. 1. People's Peace Movement in Legislative Yuan 2. Arrests of Favoring of Those Favoring Retirement of Chiang Kai-shek. 18 January 1949. CIA. CIA-RDP82-00457R002300040010-5.

11. Political Dynamics of China's Northwest. 5 June 1944. CIA. CIA.0000710371.

12. Political Information: Possibility of Chiang Kai-shek Resuming Office in National Government. 22 April 1949. CIA. CIA-RDP82-00457R002700090003-4.

13. Political Information: President Chiang Kaishek's Advisers and Personal Staff. 25 August 1948. CIA. CIA-RDP82-00457R001800480010-3. 
14. Recent Events and Trends in China. 5 September 1944. CIA. CIA.0000710373.

15. Tab. 'A.A.' (Map) Japanese and Chinese Held Areas in China (Kuang-Chou (Canton) (1944 Ed.) and Tab. 'A.B.' (Map) Situation - China - 1 February 1945 (5 Feb. 1945 Ed.). 5 February 1945. CIA. CIA-RDP7200121A000100170001-5.

16. China. Table of Contents. CIA.

17. T.V. Soong and Chiang Kai-shek. 21 August 1947. CIA. CIA-RDP82-00457R000800560009-7.

18. Charles D. J. Edgar Hoover and the AntiInterventionists: FBI Political Surveillance and the Rise of the Domestic Security State, 1939-1945. Columbus, Ohio State University Press, 2007. 197 p.

19. Gardner M. Harry Truman and Civil Rights. New York, Southern Illinois University Press, 2002. $320 \mathrm{p}$.

20. Jeans R.B. The CIA and Third Force Movements in China During the Early Cold War: The Great American Dream. Lanham, Lexington Books, $2018.342 \mathrm{p}$.

21. Kai-shek C. China's Destiny \& Chinese Economic Theory. New York, Roy Publishers, 1947.347 p.

22. Lary D. Region and Nation: The Kwangsi Clique in Chinese Politics, 1925-1937. London, Cambridge University Press, 1974. 292 p.

23. Hoover to All. 6 May 1949. National Archives and Records Administration (NARA). Record Group 65. Federal Bureau of Investigation. File: 62-7/649 (Chiang Kai-shek).

24. Hoover to Berle. 5 March 1943. NARA. RG. 65. Federal Bureau of Investigation. File: 62-7/649 (Chiang Kai-shek).

25. Hoover to San Francisco FBI and All. 9 March 1943. NARA. RG. 65. Federal Bureau of Investigation. File: 62-7/649 (Chiang Kai-shek).

26. Hoover to Vaughan. 8 July 1949. NARA. RG. 65. Federal Bureau of Investigation. File: 62-7/649 (Chiang Kai-shek).

27. Memo for D.M. Ladd. 4 March 1943. NARA. RG. 65. Federal Bureau of Investigation. File: 62-7/649 (Chiang Kai-shek).

28. Memo from Philadelphia Office to Director. 17 June 1949. NARA. RG. 65. Federal Bureau of Investigation. File: 62-7/649 (Chiang Kai-shek).

29. Radiogram from Honolulu Office to HQ. 29 November 1948. NARA. RG. 65. Federal Bureau of Investigation. File: 62-7/649 (Chiang Kai-shek).
30. SAC, Honolulu to Director. 5 July 1949. NARA. RG. 65. Federal Bureau of Investigation. File: 62-7/649 (Chiang Kai-shek).

31. SAC Hood to Director. 3 March 1943. NARA. RG. 65. Federal Bureau of Investigation. File: 62-7/649 (Chiang Kai-shek).

32. Table of Contents. NARA. RG. 65. Federal Bureau of Investigation. File: 62-7/649 (Chiang Kaishek).

33. Teletype from New York Office to HQ. 5 May 1949. NARA. RG. 65. Federal Bureau of Investigation. File: 62-7/649 (Chiang Kai-shek).

34. Hoover to Berle. 23 March 1944. NARA. RG. 65. Federal Bureau of Investigation. File: 67-571 (J. Edgar Hoover's Official and Personal Letters - China).

35. Hoover to Watson. 25 March 1944. NARA. RG. 65. Federal Bureau of Investigation. File: 67-571 (J. Edgar Hoover's Official and Personal Letters - China).

36. Memo from Director Hoover to Lawrence M.C. Smith, Chief of Special War Policies Unit. 15 January 1943. NARA. RG. 65. Federal Bureau of Investigation. File: 67-571 (J. Edgar Hoover's Official and Personal Letters - China).

37. Memo re: Soong Family. L.B. Nichols to Mr. Tolson. 8 February 1943. NARA. RG. 65. Federal Bureau of Investigation. File: 67-571 (J. Edgar Hoover's Official and Personal Letters - China).

38. Pakula H. The Last Empress: Madame Chiang Kai-shek and the Birth of Modern China. New York, Simon \& Schuster, 2009. $816 \mathrm{p}$.

39. Tanner H.M. Where Chiang Kai-shek Lost China: The Liao-Shen Campaign, 1948. New York, Indiana University Press, 2015. $384 \mathrm{p}$.

40. Leary W.M., ed. The Central Intelligence Agency: History and Documents. New York, University Alabama Press, 1984. 200 p.

41. Toller W.S. China's Destiny by Chiang KaiShek; China's Destiny and China's Economic Theory by Chiang Kai-shek, Philip Jaffe. Pacific Affairs, 1947, vol. 20, no. 3, pp. 331-335.

42. Tyson Li L. Madame Chiang Kai-shek: China's Eternal First Lady. New York, Grove Press. $2006.576 \mathrm{p}$.

43. Waller D. Wild Bill Donovan: The Spymaster Who Created the OSS and Modern American Espionage. New York, Free Press, 2012. 480 p.

44. Yu M.M. OSS in China: Prelude to Cold War. Annapolis, Naval Institute Press, 2011. 368 p. 


\section{СПЕЦСЛУЖБЫ И НАЦИОНАЛЬНАЯ БЕЗОПАСНОСТЬ}

\section{Information About the Author}

Yaroslav A. Levin, Candidate of Sciences (History), Junior Researcher, Department of World History, Law and Methods of Teaching, Samara State University of Social Sciences and Education, Maksima Gorkogo St, 65/67, 443099 Samara, Russian Federation, yaroslavlevin1992@mail.ru, https://orcid.org/0000-0001-8805-8220

\section{Информация об авторе}

Ярослав Александрович Левин, кандидат исторических наук, младший научный сотрудник кафедры всеобщей истории, права и методики обучения, Самарский государственный социально-педагогический университет, ул. Максима Горького, 65/67, 443099 г. Самара, Российская Федерация, yaroslavlevin1992@mail.ru, https://orcid.org/0000-0001-8805-8220 